\section{Performance of Tissue-cultured Primocane-fruiting Red Raspberries Following Chilling}

\author{
Jean-Pierre Privé ${ }^{1}$ and J. Alan Sullivan ${ }^{2}$ \\ Department of Horticultural Science, University of Guelph, Guelph, Ont. \\ N1G 2W1, Canada
}

Additional index words. Rubus, everbearing, fall-fruiting, relative growth rate, leaf area ratio

\begin{abstract}
Growth rates for two types of tissue-cultured plant stock for 'Heritage', 'Ruby', and 'Redwing' red raspberry (Rubus idaeus L.) were examined. Actively growing plantlets from the greenhouse $(G)$ were compared to cold-treated $(C T)$ plantlets from cold storage. The greatest differences between these two occurred during the first 6 weeks after planting. At 4 weeks, CT plants for all cultivars had longer canes and internodes, sometimes twice that of $G$ plants. Although 'Heritage' had greater total plant dry weights following chilling, 'Ruby' and 'Redwing' had less. Chilling had no effect on 'Heritage' root growth but did reduce root dry weight for 'Redwing' and 'Ruby'. Relative growth rate (RGR) and leaf area ratio (L-AR) were more effective variables for analyzing growth as they considered differences in initial biomass and cane number and provided a better representation of the data during the initial 6 weeks of growth. All cultivars showed a greater total plant RGR and LAR for the CT plants at 6 weeks. During the first 4 weeks, the $G$ plants were more efficient producers of root dry matter while the CT plants were more efficient producers of cane dry matter. By 6 weeks, the $G$ plants had partitioned a greater percentage of their assimilates into cane growth while the leaves, canes, and roots of the CT plants contributed equally to total RGR. No difference in total or individual component RGR was observed after 6 weeks.
\end{abstract}

Raspberry growers have traditionally used cold-treated bare root stock for planting until plants from tissue culture became an option during the mid-1980s. Now, $\approx 15 \%$ of bramble acreage in North America is planted using tissue-cultured plants, and this percentage should rise in the future since tissue-cultured plants provide a greater assurance of diseasefree plant material, grow more rapidly and uniformly than conventionally propagated transplants, and generally produce higher yields early in the life of the planting (Pritts and Handley, 1989). These ex vitro plantlets, once established and acclimatized, can also be planted directly in the field after danger of spring frost has passed (Bartel et al., 1988). Depending on the time of year and the supplier, these plantlets can either be acquired directly from the greenhouse while actively growing or from cold storage as coldtreated (CT) dormant plants (Fig. 1). G and CT plants are usually available from March to June and November to April, respectively. All in vitro plants originate from meristem culture from the same greenhouse mother plants. Due to the overlap in availability of

Received for publication 15 June 1990. Financial assistance from Agriculture Canada to J-P.P. is acknowledged gratefully. Appreciation is extended to Nourse Farms for the donation of plant material. The cost of publishing this paper was defrayed in part by the payment of page charges. Under postal regulations, this paper therefore must be hereby marked advertisement solely to indicate this fact.

'Graduate Student.

${ }^{2}$ Assistant Professor.
CT and G plants in March and April, purchasers may have the option of choosing the type of planting stock they wish. Chilling temperatures are known to enhance root growth in woody species (Farmer, 1975; Lathrop and Mecklenburg, 1971), but the effect on tissue-cultured raspberry plant growth is unknown.

In a preliminary study comparing three CT and three G tissue-cultured 'Heritage' plants growing in the greenhouse, large differences in plant height were observed. CT plants elongated much faster than $G$ plants, with the greatest differences occurring during the initial 8 weeks after planting. This growth originated from the plantlets' basal buds while growth from the original cane did not regenerate. The objective of the present study was to compare the growth rates of the two types of tissue-cultured plant stocks (CT vs. G) for the primocane-fruiting 'Heritage', 'Redwing', and 'Ruby' red raspberries.

For each cultivar, 50 tissue-cultured CT and $G$ plantlets rooted in cells were potted in 6-liter pots with a 2 pasteurized fox sandy loam (Typic Hapludalf) : 1 perlite mixture. All plants were placed outdoors on 24 May 1989 in a completely randomized design. All dormant canes were removed from the CT plants at time of potting since growth originates from a basal bud. Plants were fertilized with Nutricote 14-8-8 ME Type 100day release fertilizer (Chisso-Asahi Fert. Co., Tokyo; g/pot, $3.1 \mathrm{~N}-1.8 \mathrm{P}-1.8 \mathrm{~K}$ ) and watered as required, using drip irrigation. Monthly means for June, July, and part of August were $17.3 \pm 5 \mathrm{C}, 20.1 \pm 6 \mathrm{C}$, and $19.1 \pm$
$6 \mathrm{C}$, respectively. Maximum daily temperatures exceeded $30 \mathrm{C}$ on 5 days.

The following data were collected at planting and 4,6,8, and 10 weeks thereafter on three plants from each treatment for each cultivar: number of canes, cane length and diameter, number of nodes, number of leaves, leaf area and leaf, cane, and mot dry weights. Dry weights were determined after oven drying at $80 \mathrm{C}$ for 1 week.

Root, cane, and total plant relative growth rates $(\mathrm{RGR}=$ rate of dry weight increase per unit dry weight per unit time) and leaf area ratio $(\mathrm{LAR}=$ ratio of total leaf area to whole plant dry weight) were calculated as follows (Hunt, 1982): $\mathrm{RGR}_{2-1}=\mathrm{LnW}_{2}-$ LNW ${ }_{1} / \mathrm{T}_{2}-\mathrm{T}_{1} ; \quad \mathrm{LAR}=\mathrm{LA} / \mathrm{W}$, where $\mathrm{W}_{2}$ and $\mathrm{W}_{1}$ are mean plant dry weight at harvest times $\mathrm{T}_{2}$ and $\mathrm{T}_{1}$, respectively, and LA is leaf area per plant. Week was used as the time unit for this analysis. All growth characters were tested by analysis of variance using the General Linear Models procedure of the Statistical Analysis System program package (SAS Institute, Cary, N.C.) with contrasts for planned comparisons between $\mathrm{CT}$ and $\mathrm{G}$ plants for each date.

During the first 4 weeks, all CT plants had longer canes and internodes, sometimes twice the length of the G plants (Table 1). Except for 'Ruby' at 10 weeks, the number of nodes was not affected by chilling. Total plant dry weight was greater in the CT 'Heritage' plants at 6 and 10 weeks due to increased cane vigor. At 10 weeks, 'Ruby' and 'Heritage', but not 'Redwing', showed a reduction in total plant dry weight following chilling.

The partitioning of dry weight into the leaves, canes, and roots differed among cultivars over time. Following chilling, only 'Heritage' CT plants had greater cane vigor (length, diameter, and dry weight). Leaf area and dry weight at 6 weeks were greater for 'Heritage' but lower for 'Ruby' following chilling. 'Redwing' CT plants had less leaf dry weight than $G$ plants at 6 weeks, but more at 10 weeks. However, when the LARs of the plants were compared, all cultivars reacted similarly. At 4 weeks, LAR for the $\mathrm{CT}$ and $\mathrm{G}$ plants was 153 and $115 \mathrm{~cm}^{2} \cdot \mathrm{g}^{-1}$, respectively. This ratio was maintained until 6 weeks for the CT plants while LAR for the
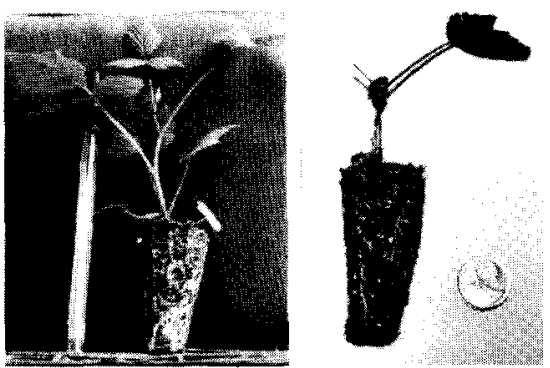

Fig. 1. Actively growing plantlet from greenhouse (G) at left and dormant plantlet from cold storage (CT) at right (shown with Canadian quarter, $2.4 \mathrm{~cm}$ in diameter). The dormant cane was removed since growth is initiated from a basal bud. 
Table 1. Effect of chilling on growth characters of three tissue-cultured primocane-fruiting red raspberry cultivars.

\begin{tabular}{|c|c|c|c|c|c|c|c|c|c|c|c|c|c|}
\hline \multirow[b]{2}{*}{ Cultivar } & \multirow[b]{2}{*}{ Week } & \multirow[b]{2}{*}{ Treatment $^{z}$} & \multicolumn{4}{|c|}{ Cane } & \multirow[b]{2}{*}{$\begin{array}{c}\text { Nodes } \\
\text { (no.) }\end{array}$} & \multirow[b]{2}{*}{$\begin{array}{c}\text { Internode } \\
\text { length } \\
\text { (cm) }\end{array}$} & \multicolumn{3}{|c|}{ Leaf } & \multirow[b]{2}{*}{$\begin{array}{c}\text { Root } \\
\text { dry wt } \\
\text { (g) }\end{array}$} & \multirow[b]{2}{*}{$\begin{array}{c}\text { Total } \\
\text { dry wt } \\
\text { (g) }\end{array}$} \\
\hline & & & No. & $\begin{array}{c}\text { Length } \\
(\mathrm{cm})\end{array}$ & $\begin{array}{l}\text { Diam } \\
(\mathrm{cm})\end{array}$ & $\begin{array}{l}\text { Dry } \\
\text { wt } \\
\text { (g) }\end{array}$ & & & No. & $\begin{array}{c}\text { Total } \\
\text { area } \\
\left(\mathrm{cm}^{2}\right) \\
\end{array}$ & $\begin{array}{l}\text { Dry } \\
\text { wt } \\
(\mathrm{g}) \\
\end{array}$ & & \\
\hline \multirow[t]{6}{*}{ Heritage } & 4 & $\mathrm{CT}$ & 3.0 & $17^{*}$ & 0.8 & $0.25^{*}$ & 21 & $0.9^{*}$ & 21 & 251 & 1.02 & 0.40 & 1.67 \\
\hline & & $\mathrm{G}$ & 3.7 & $9^{*}$ & 1.0 & $0.13^{*}$ & 26 & $0.3^{*}$ & 23 & 229 & 1.10 & 0.62 & 1.85 \\
\hline & 6 & CT & 3.0 & $44^{* *}$ & $1.2^{* *}$ & $1.13^{*}$ & 27 & $1.6^{* *}$ & 28 & $883^{* *}$ & $5.03^{*}$ & 1.47 & $7.63^{* *}$ \\
\hline & & G & 2.0 & $13^{* *}$ & $0.9^{* *}$ & $0.50^{*}$ & 23 & $0.6^{* *}$ & 20 & $432^{* *}$ & $2.60^{*}$ & 1.16 & $4.27^{* *}$ \\
\hline & 10 & $\mathrm{CT}$ & 2.7 & 69 & $1.2^{* *}$ & $3.30^{* *}$ & 39 & $1.8^{*}$ & 37 & 1470 & 11.40 & 2.53 & $17.2^{* *}$ \\
\hline & & $\mathrm{G}$ & 3.0 & 58 & $1.6^{* *}$ & $1.93^{* *}$ & 41 & $1.4^{*}$ & 38 & 1690 & 9.47 & 1.97 & $13.4^{* *}$ \\
\hline \multirow[t]{6}{*}{ Ruby } & 4 & $C T$ & 3.0 & $34^{*}$ & 0.7 & 0.38 & 26 & $1.3^{*}$ & 26 & 290 & 1.03 & $0.38^{*}$ & $1.79^{*}$ \\
\hline & & G & 3.0 & $15^{*}$ & 0.8 & 0.24 & 24 & $0.7^{*}$ & 23 & 287 & 1.23 & $0.83^{*}$ & $2.40^{*}$ \\
\hline & 6 & CT & 2.7 & 35 & 0.8 & 0.77 & 21 & $1.7^{* *}$ & 22 & $569^{* *}$ & $3.10^{*}$ & $0.87^{*}$ & $4.73^{*}$ \\
\hline & & $\mathrm{G}$ & 3.3 & 30 & 1.2 & 1.10 & 28 & $1.0^{* *}$ & 29 & $954^{* *}$ & $5.23^{*}$ & $1.67^{*}$ & $8.00^{*}$ \\
\hline & 10 & $\mathrm{CT}$ & 3.3 & 79 & 1.1 & 2.00 & $34^{* *}$ & $2.3^{*}$ & 34 & 1470 & 9.03 & $2.07^{*}$ & $13.1^{*}$ \\
\hline & & $\mathrm{G}$ & 3.0 & 89 & 1.2 & 2.57 & $48^{* *}$ & $1.9^{*}$ & 37 & 1520 & 10.53 & $2.87^{*}$ & $16.0^{*}$ \\
\hline \multirow[t]{6}{*}{ Redwing } & 4 & CT & 2.7 & $14^{*}$ & 0.4 & 0.15 & 17 & $0.9^{*}$ & 13 & 107 & 0.50 & $0.18^{*}$ & $0.82^{*}$ \\
\hline & & G & 1.7 & $6^{*}$ & 0.5 & 0.11 & 15 & $0.4^{*}$ & 11 & 154 & 0.79 & $0.53^{*}$ & $1.42^{*}$ \\
\hline & 6 & CT & 1.3 & 16 & 0.5 & 0.40 & 12 & $1.4^{\circ}$ & 10 & 298 & $1.17^{*}$ & 0.77 & $2.33^{*}$ \\
\hline & & $\mathrm{G}$ & 1.7 & 17 & 0.7 & 0.47 & 15 & 1.1 & 17 & 433 & $2.87^{*}$ & 1.07 & $4.40^{*}$ \\
\hline & 10 & CT & 1.7 & 51 & 0.8 & 1.77 & 31 & 1.6 & 27 & 1260 & $8.33^{*}$ & $1.37^{*}$ & 11.5 \\
\hline & & G & 2.0 & 47 & 1.0 & 1.43 & 25 & 2.0 & 23 & 1020 & $6.87^{*}$ & $2.17^{*}$ & 10.5 \\
\hline
\end{tabular}

${ }^{2} \mathrm{CT}$ plants exposed to a cold treatment; $\mathrm{G}=$ plants without a cold treatment. Means of three plants for each cultivar, week, and treatment. Contrasts were used to separate mean values between $\mathrm{CT}$ and $\mathrm{G}$ at each date for each cultivar, respectively. Contrasts significant at $P=0.05(*)$ or $0.01(* *)$.

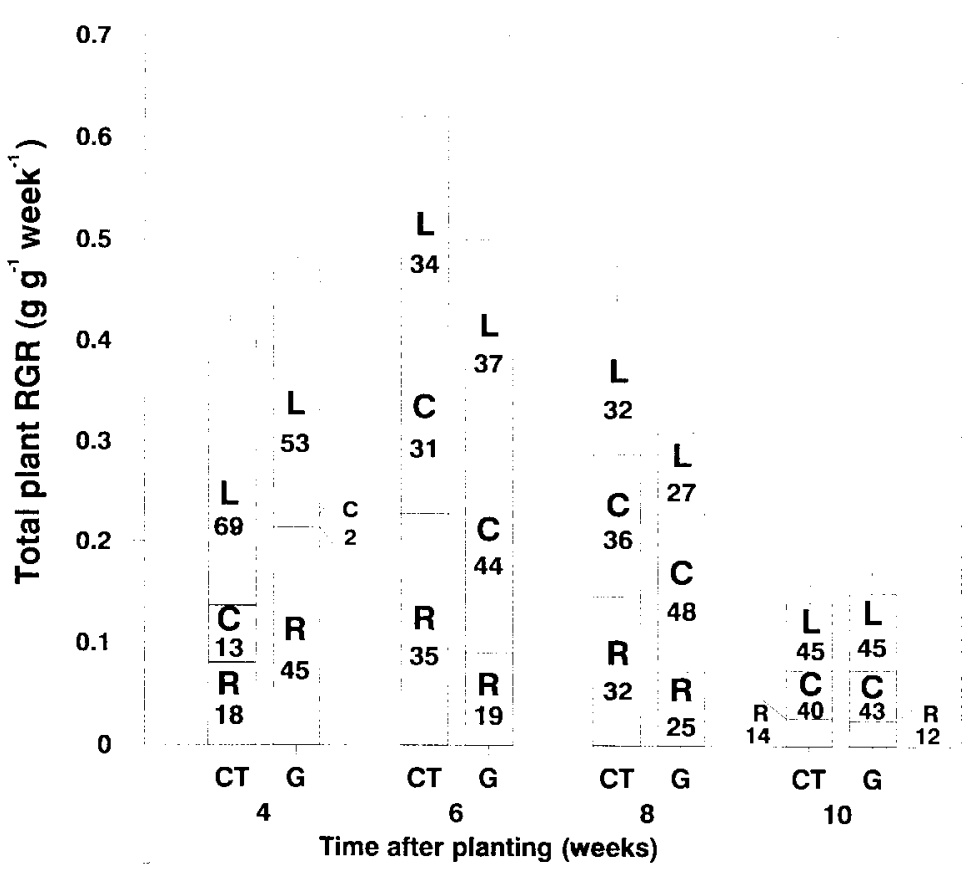

Fig. 2. The influence of cold-treated (CT) and green $(\mathrm{G})$ plants on total plant relative growth rate (RGR) with the percent contribution by the leaves (L), canes (C), and roots (R). Data averaged among 'Heritage', 'Redwing', and 'Ruby' primocane-fruiting red raspberries. Vertical bars indicate half standard error of the mean for the planned comparisons between CT and G plants for each date.

G plants had dropped to $105 \mathrm{~cm}^{2} \cdot \mathrm{g}^{-1}$. This difference suggests that, over the 6 weeks, the CT plants were more efficient photosynthesizes in relation to their respiring components. Except for 'Redwing' at 6 weeks, both 'Redwing' and 'Ruby' had greater root dry weight accumulation in the $\mathrm{G}$ plants. There was no effect of chilling on 'Heritage' root dry weight.

Although the CT 'Heritage' plants grown outdoors had greater cane vigor than the $\mathrm{G}$ plants, it was less than that observed from the preliminary study with the 'Heritage' plants grown in the greenhouse. Outdoor temperatures fluctuate more than greenhouse temperatures, suggesting that the stress conditions during the 1989 season may have reduced the large differences detected between the two types of stock when grown in the greenhouse. Root development is a greater concern than cane length when establishing a raspberry crop. At 4 weeks, plants exhibiting the greatest cane growth also had the lowest root growth (Table 1). The two traits may in fact be inversely related since carbohydrates diverted to top growth are not available for root growth.

The analysis of total plant dry weight accumulation may be confounded by the large magnitude of dry weight changes over the course of the study. This may obscure differences present during the early stages of development. Since this early period is of prime importance in this study and to compensate for the differences in initial biomass and cane number between planting stock types, RGR was calculated. RGR expresses the plant's efficiency to accumulate new dry matter and determines the relationship between shoot and root growth. The three cultivars showed similar RGRs, therefore, RGR data presented are averaged among cultivars. Total plant RGR followed a typical progression for the slope of a logistic function (Hunt, 1982), with the point of inflection occurring at 6 weeks (Fig. 2). At this time, total plant RGR was greater for the CT plants.

Although data for roots, canes, and leaves differed among cultivars (Table 1), they were similar when analyzed as LAR or as percentage contribution by each component to the total RGR. During the first 4 weeks, on average, the $G$ plants diverted similar amounts of carbohydrates to cane and leaf growth $(45 \%)$ and to root growth (55\%) (Fig. 2). In contrast, the CT plants partitioned most of their assimilates to above-ground growth $(82 \%)$ and less to root growth $(18 \%)$. The increase in percentage partitioned to the above-ground growth by the CT plants was due to a higher proportion of assimilates diverted to cane growth rather than to leaf growth. By 6 weeks, the G plants had had their greatest increase in cane growth, while the root and cane components of the CT plants increased their contribution to total plant growth. This increase in partitioning to the roots, canes, and leaves by the CT plants at 6 weeks was sufficient to cause the total plant RGR of the CT plants to be greater than for the $\mathrm{G}$ plants. Thereafter, differences in leaf, cane, root, or total RGR were less or absent among treatments.

In perennial plants, growth rates increase and decrease in a series of steps with varying magnitudes depending on environmental 
conditions (Hunt, 1982). We found that, initially, CT plants were more efficient producers of cane dry matter but at the expense of root growth. This result differs from woody species with greater root growth when exposed to chilling temperatures (Farmer, 1975; Lathrop and Mecklenburg, 1971). Root growth was stimulated by factors originating in the stem for northern red oak and by auxins when applied to decapitated plants (Farmer, 1975). This hormonal interaction between shoots and roots was not present in this study since the CT canes were cut prior to planting. Another apparent difference is the use of bare-root stock (Farmer, 1975; Lathrop and Mecklenburg, 1971) compared to tissue-cultured stock. Of the two types of plant stocks used in this study, the G plants were probably the most influenced by the in vitro environment and transplant shock. In comparison, the CT plants were influenced to a lesser extent since plantlets had been removed from the in vitro environment for a longer period, subjected to low temperatures, and because the source of new growth was from a new basal bud. Epigenetic changes induced by tissue-cultured environments have been reported for raspberry (Donnelly and Vidaver, 1984). Plantlet leaves retained from culture had lower net assimilation rates than newly formed leaves. Acclimatization ex vitro was time-dependent and required the production of new leaves initiated in the new environment. Medium hormones are also known to influence ex vitro growth of strawberry and blackberry (Swartz et al., 1981, 1983) and the hormone effect may be reduced by a cold storage period.

To summarize, total plant dry weight and the partitioning of dry matter to the leaves, canes, and roots differed between the CT and $\mathrm{G}$ plants for all three cultivars. 'Heritage' was the only cultivar to show greater total plant dry weight following chilling. Differences in growth and development of primocane-fruiting red raspberry cultivars are expected and are influenced largely by temperature and daylength (Keep, 1988). Total plant RGR and its percentage contribution by the leaves, canes, and roots proved to be an appropriate method to clarify differences in cane number and initial biomass. It also allowed for a better representation of growth during the initial stages of development between CT and G plants for all cultivars. At 4 weeks, the $\mathrm{G}$ plants had partitioned a greater percentage of their carbohydrates into root growth and less into cane growth while the opposite was true for CT plants. Only at 6 weeks was total plant RGR significantly greater for the CT plants. Thereafter, RGR became similar for both $\mathrm{CT}$ and $\mathrm{G}$ plants. In the establishment year of a raspberry crop, root development is of greater concern than above-ground growth. Chilling had no influence on 'Heritage' root growth but did reduce root dry weight for 'Ruby' and 'Redwing'. However, when all cultivars were tested using RGR, only at 4 weeks was the root component of the CT plants reduced. Based on this result, growers need not worry which type of planting stock they purchase from the propagator. However, when these plants are used for research purposes, the growth differences between $\mathrm{CT}$ and $\mathrm{G}$ must be considered.

\section{Literature Cited}

Bartel, S., H. Bartholomew, M.A. Ellis, R.C Funt, S.T. Nameth, R.L. Overmyer, H. Schneider, W.J. Twarogowski, and R.N. Williams. 1988. Brambles: production, management and marketing. Ohio Coop. Ext. Serv. Bul. 783.

Donnelly, D.J. and W.E. Vidaver. 1984. Pigment content and gas exchange of red raspberry in vitro and ex vitro. J. Amer. Soc. Hort. Sci. 109:177-181.

Farmer, R. E., Jr. 1975. Dormancy and root regeneration of northern red oak. Can. J. For. Res. 5:176-185.

Hunt, R. 1982. Plant growth curves: The func- tional approach to plant growth analysis. Univ. Park Press, Baltimore, Md.

Keep, E. 1988. Primocane (autumn)-fruiting raspberries: a review with particular reference to progress in breeding. J. Hort. Sci. 63(1):1-18.

Lathrop, J.K. and R.A. Mecklenburg. 1971. Root regeneration and root dormancy in Taxus spp. J. Amer. Soc. Hort. Sci. 96:111-114.

Pritts, M. and D. Handley. 1989. Bramble production guide. NRAES-35, Northeast Reg. Agr. Eng. Serv. Coop. Ext. Ithaca, N.Y.

Swartz, H. J., G.J. Galetta, and R.H. Zimmerman. 1981. Field performance and phenotypic stability of tissue culture propagated strawberries. J. Amer. Soc. Hort. Sci. 106: 667-673.

Swartz, H. J., G.J. Galetta, and R.H. Zimmerman. 1983. Field performance and phenotypic stability of tissue culture propagated thornless blackberries. J. Amer. Soc. Hort. Sci. 108:285290 . 